\title{
Molecular Identification and Evaluation of Indigenous Bacterial Isolates for Their Plant Growth Promoting and Biological Control Activities against Fusarium Wilt Pathogen of Tomato
}

\author{
Amanul Islam (D)*, Md. Shahinur Kabir (D), and Abul Khair (D) \\ Department of Botany, Jahangirnagar University, Savar, Dhaka-1342, Bangladesh \\ (Received on June 15, 2018; Revised on November 22, 2018; Accepted on December 5, 2018)
}

In search of an effective biological control agent against the tomato pathogen Fusarium oxysporum f. sp. lycopersici, rhizospheric soil samples were collected from eight agro-ecological zones of Bangladesh. Among the bacteria isolated from soil, 24 isolates were randomly selected and evaluated for their antagonistic activity against $F$. oxysporum f. sp. lycopersici. The two promising antagonistic isolates were identified as Brevundimonas olei and Bacillus methylotrophicus based on morphological, biochemical and molecular characteristics. These two isolates were evaluated for their biocontrol activity and growth promotion of two tomato cultivars (cv. Pusa Rubi and Ratan) for two consecutive years. Treatment of Pusa Rubi and Ratan seeds with $B$. olei prior to inoculation of pathogen caused $44.99 \%$ and $41.91 \%$ disease inhibition respectively compared to the untreated but pathogen-inoculated control plants. However, treatment of Pusa Rubi and Ratan seeds with B. methylotrophicus caused $24.99 \%$ and $39.20 \%$ disease inhibition respectively. Furthermore, both the isolates enhanced the growth of tomato plants. The study re-

*Corresponding author.

Phone) +8801819926160, FAX) +880-2-7791052

E-mail)progoti17@gmail.com

ORCID

Amanul Islam

http://orcid.org/0000-0003-0787-757X

Md. Shahinur Kabir

http://orcid.org/0000-0002-0411-7797

Abul Khair

http://orcid.org/0000-0001-7235-683X

(c) This is an Open Access article distributed under the terms of the Creative Commons Attribution Non-Commercial License (http:// creativecommons.org/licenses/by-nc/4.0) which permits unrestricted noncommercial use, distribution, and reproduction in any medium, provided the original work is properly cited.

Articles can be freely viewed online at www.ppjonline.org. vealed that these indigenous bacterial isolates can be used as an effective biocontrol agent against Fusarium wilt of tomato.

Keywords : biological control, Fusarium oxysporum, fusarium wilt, plant growth promoting rhizobacteria, tomato

Handling Editor : Lee, Yong Hoon

Among the fungal diseases of tomato, Fusarium wilt is one of the most serious ones throughout the world, especially in Bangladesh. This disease is caused by soil-borne pathogenic fungi $F$. oxysporum f. sp. lycopersici. Fusarium wilt of tomato causes $10-90 \%$ yield loss in temperate region (Singh and Kamal, 2012). It has been estimated that this pathogen is responsible for $60-70 \%$ yield loss of tomato in Bangladesh (Raihan et al., 2016). The control of Fusarium wilt of tomato is difficult due to the ability of this pathogen to proliferate within vascular tissues of the host. Fungicides cannot effectively control this soil-borne pathogen. Moreover, application of fungicides may also kill some other microorganisms beneficial to tomato plants. In order to address such problems, in an environment friendly manner, biological control agents can be employed.

Earlier studies demonstrated that some microorganisms inhabiting in the rhizosphere region have the potentiality to enhance plant growth (Ge et al., 2016; Guo et al., 2004). Bacterial isolates from local agro-ecological environment and rhizosphere of specific plant is likely to be well adapted and perform better in this respect (Whipps, 1997). In order to get desired result, it is important to identify and use region-specific new microbial strains which can be used as potential biocontrol agents and plant growth promoters. Information pertaining to the use of rhizosphere inhabiting bacterial isolates from different agro-ecological regions of 
Bangladesh and their application for biological control is inadequate, particularly in case of tomato. Therefore, the present study was conducted to find novel indigenous rhizospheric bacterial isolates from different agro-ecological zones (AEZs) of Bangladesh and to evaluate their biocontrol potential against Fusarium wilt of tomato and their plant growth promoting ability.

\section{Materials and Methods}

Collection of soil sample. In order to collect indigenous biocontrol agents, plant rhizosphere soil samples were collected from fields of four different crops growing in eight different agro-ecological zones (AEZs) of Bangladesh (Table 1). The soil samples were collected from rhizosphere of rice (Oryza sativa L.), jute (Corchorus capsularis L.), bean (Lablab niger Medikus) and sesban (Sesbania bispinosa (Jacq.) W. Wight, following standard methods (Malleswari and Bagyanarayana, 2013).

Isolation and selection of bacteria. One gram of each of the collected soil samples was weighed and placed in the test tube containing $9 \mathrm{ml}$ of $0.9 \%$ saline (Bahig et al., 2008). Ten folds serial dilution was made and an aliquot was spread onto nutrient agar (NA) plates. The plates were incubated at $28 \pm 2^{\circ} \mathrm{C}$ for $24 \mathrm{~h}$. The individual colonies formed on the NA plates were picked up with sterilized loop and transferred to fresh NA plates for further purification and isolation of single colony. The plates were incubated at $28 \pm 2^{\circ} \mathrm{C}$ for $24 \mathrm{~h}$. The single colonies developed separately at the last tip of the streaks were transferred to NA slants to serve as pure culture.
Morphological and growth characteristics of the isolates. Colonies of all the isolated rhizobacterial isolates formed on NA plates were evaluated for size, pigmentation, form, margin, elevation as described in Bergey's Manual of Determinative Bacteriology (Bergey and Holt, 2000). Furthermore, tolerances of bacteria to $\mathrm{pH}$, salinity and varying temperatures were evaluated using a turbidometric method (Chookietwattana and Maneewan, 2012).

Phytopathogen. The soil-borne pathogen $F$. oxysporum used in this study were obtained from the Plant Pathology Division, Bangladesh Agricultural Research Institute, Gazipur, Bangladesh.

Screening of the isolates for biocontrol potential. All the 24 isolates were assayed in vitro for interactions with soilborne phytopathogen $F$. oxysporum on PDA media. Bioassay was studied by dual culture technique as per Ramanathan et al. (2002). Five millimeters mycelial discs were cut from young growing edge of the fungus from seven days old culture with a sterilized cork borer and placed at one side of a Petri plate. The 24 bacterial isolates were streaked aseptically parallel to the fungus at a distance of $15-20 \mathrm{~mm}$ and incubated at $28 \pm 2^{\circ} \mathrm{C}$ for 10 days. Three replications were maintained for each isolate. The inhibition zone between the two cultures was measured in nearest millimeter. After 10 days incubations the percent inhibition of the fungus was calculated by using the formula:

$$
\text { Growth inhibition }(\%)=\frac{\mathrm{R} 1-\mathrm{R} 2}{\mathrm{R} 1} \times 100
$$

Table 1. Location of the agricultural fields for the collection of rhizospheric soil samples

\begin{tabular}{|c|c|c|c|}
\hline Rhizosphere soil source & Code name (No. of isolates) & $\begin{array}{l}\text { Place of collection } \\
\text { (Thana, District) }\end{array}$ & $\begin{array}{l}\text { Agro-Ecological Zones } \\
\text { (AEZ) covered }\end{array}$ \\
\hline \multirow{6}{*}{ Rice (Oryza sativa L.) } & Prk1, Prk2, Prk3, Prk4 (4) & Kumarkhali, Kushtia & High Ganges river floodplain \\
\hline & $\operatorname{Prd} 2, \operatorname{Prd} 5(2)$ & Shotogram, Dinajpur & Old Himalayan piedmont plain \\
\hline & Prju2, Prju3, Prju3b (3) & $\begin{array}{c}\text { Jahangirnagar University } \\
\text { Campus, Savar, Dhaka }\end{array}$ & Madhupur tract \\
\hline & Prsp1, Prsp2, Prsp3 (3) & Jhinaigathi, Sherpur & Northern and eastern piedmont plains \\
\hline & Prbo, Prbo4, Prbo5 (3) & Ujirpur, Barisal & Low high Ganges river floodplain \\
\hline & Prb1, Prb2 (2) & Bogra sadar, Bogra & Level barind tract \\
\hline \multirow{2}{*}{ Bean (Lablab niger Medik) } & Pbbb1 (1) & Nobinagar, Brahmanbaria & Old Meghna estuarine floodplain \\
\hline & $\mathrm{Pbm} 3$ (1) & Gouripur, Mymensingh & Old Brahmaputra floodplain \\
\hline Jute (Corchorus capsularis L.) & Pjbb, Pjbb1, Pjbb3, Pjbb5 (4) & Nobinagar, Brahmanbaria & Old Meghna estuarine floodplain \\
\hline $\begin{array}{l}\text { Sesban (Sesbania bispinosa } \\
\text { (Jacq.) W. Wight) }\end{array}$ & Pdbb (1) & Nobinagar, Brahmanbaria & Old Meghna estuarine floodplain \\
\hline
\end{tabular}


Where

$\mathrm{R}_{1}=$ Radius (mm) of the fungus from the center of the colony towards the centre of the plate in the absence of antagonistic bacteria

$\mathrm{R}_{2}=$ Radius (mm) of the fungus from center of the colony towards the antagonistic bacteria

Biochemical tests. On the basis of consistent antagonism and stress tolerance activities, two bacterial isolates Prb1 and $\operatorname{Prd} 2$ showing promising activity compared to the control were selected for further characterization based on standard biochemical tests (Schaad et al., 2001). The tests conducted were Gram reaction, catalase activity, oxidase activity, nitrate reduction, arginine decarboxylase activity, gelatin liquefaction, urease activity, levan formation from sucrose and utilization of glucose, maltose, lactose, xylose and mannitol. Results of these tests were scored as either positive or negative.

Production of extracellular hydrolytic enzymes such as amylase, protease and cellulase were tested by growing each bacterial isolate on the medium containing enzyme substrate; skim milk for protease assay (Naik et al., 2008), carboxymethyl cellulose for cellulase assay (Bhakthavatchalu et al., 2013) and starch for amylase assay (Shruti et al., 2013). Solid agar plates amended with $0.44 \%$ of Lglycine was used for qualitative hydrogen cyanide production following the method of Bakker and Schippers (1987). The colour change of the filter paper from yellow to light brown, moderate brown or strong brown was examined for putative HCN production. Siderophore production was detected according to Naik et al. (2008). For assessment of growth on nitrogen free media Norris agar plates was used as described by Kumar et al. (2012).

Molecular identification. The molecular identification of two isolates was carried out by the 16S rRNA gene sequencing and subsequent analysis using NCBI-BLAST database (Altschul et al., 1990). For genomic DNA isolation, the selected two isolates were grown to log phase. The cells were harvested by centrifugation and genomic DNA was isolated using Maxwell 16 automated DNA extractor (USA) and quantified using NanoDrop spectrophotometer (Thermo Scientific, USA). The 16S rRNA gene of each of the isolates were amplified by PCR using the primers 27F(AGAGTTTGATCMTGGCTCAG) and 1492R (GGTTACCTTGTTACGACTT) according to Sudini et al. (2011). The PCR products were analyzed on 1\% agarose gel and desired band was excised and purified. The PCR product was sequenced in both directions at 1st Base Laboratories, Malaysia using an automated DNA sequencer
(Genetic Analyzer ABI 3500, Thermo Fisher Scientific Inc., USA). The resulting DNA sequence was compared by NCBI-BLAST database (Altschul et al., 1990). Based on the highest degree of similarity, identity for the bacterial isolates was assigned.

For phylogenetic analysis, the 16S rRNA gene sequences were aligned with the Clustal W program and the tree was constructed with the maximum likelihood method based on the Tamura-Nei model (Tamura and Nei, 1993) integrated in the MEGA7 software (Kumar et al., 2016). The phylogenetic tree was tested with 1,000 bootstrap replicates.

Survival of the isolates. The two bacterial isolates were grown in nutrient broth medium and stored at constant temperature $\left(28 \pm 2^{\circ} \mathrm{C}\right)$. The samples taken from the growth medium and diluted to appropriately. The diluted cell suspensions $(100 \mu \mathrm{l})$ were inoculated onto the solid NA media. The plates were incubated at $\left(28 \pm 2^{\circ} \mathrm{C}\right)$ temperature for $24 \mathrm{~h}$. The number of colony forming units (cfu) was counted after one day of incubation at each week up to 35 days.

Effect of ferric ion on antagonistic activity. In order to determine the threshold level of iron at which siderophore biosynthesis is repressed, the biological agents were inoculated in King's B medium supplemented with different concentrations of $\mathrm{FeCl}_{3}(0,50,70$ and $100 \mu \mathrm{M})$. After inoculation, antagonism was observed following the method of Akköprü and Demir (2005).

Root colonization bioassay. Root colonization bioassay was carried out following the procedure described by Silva et al. (2003). Surface sterilized tomato seeds were soaked in $25 \mathrm{ml}$ of bacterial suspension $\left(\mathrm{OD}_{600}=0.1\right)$ and then transferred to sterile $0.6 \%$ water agar tubes. The seedlings were allowed to grow at room temperature $\left(28 \pm 2^{\circ} \mathrm{C}\right)$. Visual observations were performed daily in order to detect bacterial growth around arising roots.

Interaction studies of bacteria with other non-target soil beneficial organisms. The two selected bacterial isolates namely, Prb1 and Prd 2 were tested for their interaction with other beneficial microorganism $B$. subtilis, Trichoderma harzianum and T. reesei. Pure culture of $B$. subtilis, T. harzianum, T. reesei obtained from the Plant Pathology Laboratory, Department of Botany, JU. Each of these three cultures were inoculated at a distance of $2 \mathrm{~cm}$ with respective two bacterial isolates and observed for the inhibition zone. The inoculated plates were observed for growth at regular intervals. 
Effect of selected bacterial isolates on disease control and plant growth parameters of tomato. Experiment was conducted to observe the effect of selected bacterial isolates on disease control and growth promotion of tomato plant in pot culture condition. Two most popular cultivars of tomato (cv. Ratan and Pusa Ruby) in Bangladesh were used in this study (Khalequzzaman et al., 2002; Mistry et al., 2008). For seed surface sterilization and water formulated bacterial inoculation, the method described by Weller and Cook (1983) was followed. For seed treatment, cell suspension containing approximately $1 \times 10^{8} \mathrm{cfu} / \mathrm{ml}$ was applied to surface sterilized seeds. Seedling vigor test in the laboratory was performed using the standard roll towel method (ISTA, 1999). After 10 days of incubation, observation pertaining to (a) germination (b) dead seed (c) seedling weight (d) root length (e) shoot length and (f) vigor index were recorded.

Germination percentage was calculated by using the formula (ISTA, 1976):

Percentage of germination $=$

No. of seeds germinated

Total No. of seeds taken for germination

Vigor of the seedling was determined by using the following formula (ISTA, 1996):-

Vigor Index $=($ Mean of root length + Mean of shoot length) $\times \%$ of Seed germination

Pot culture experiment was conducted during tomato growing season in 2015-16 and 2016-17 to assess interaction between the bacterial isolates and the targeted wilt pathogen. Soil used in the pots were homogenized and sterilized following the method described by Khalequzzaman et al. (2002). Treated seeds were permitted to dry for $6 \mathrm{hrs}$ before planting. There were three replications of each treatment and the pots were arranged in randomized manner. Inoculations of plants with pathogen were performed after 3 weeks of sowing. Seedlings were inoculated with the spore and cell suspension of $F$. oxysporum by the soilsoak method (Tans-Kersten et al., 2001). The experimental setup included the following treatments: (1) non-infested soil (control), (2) soil treated with $F$. oxysporum only, (3) $F$. oxysporum + Prd2, (4) F. oxysporum + Prb1, (5) Prd2 only and (6) Prb1 only. The disease incidence was recorded up to 30 days after pathogen inoculation. To find out disease incidence of Fusarium wilt of tomato, method described by Song et al. (2004) was followed. Percent Disease Index (PDI) was calculated by the following formula:

$$
\mathrm{PDI}=\frac{\mathrm{S}(\text { Disease scale } \times \text { plant number in that class }}{\text { Highest scale } \times \text { total number of plants }} \times 100
$$

Biological control efficacy (BCE) was calculated according to Guo et al. (2004):

$$
\begin{aligned}
& \mathrm{BCE}=\left(\mathrm{D}_{\mathrm{c}}-\mathrm{D}_{t} / \mathrm{D}_{\mathrm{c}}\right) \times 100 \% \\
& \text { Where, } \mathrm{D}_{\mathrm{c}} \text { disease of control, } \\
& \left.\mathrm{D}_{\mathrm{t}} \text { disease of the treatment }\right)
\end{aligned}
$$

The observations with respect to the growth parameters including plant height, number of leaves, leaf area (Carmassi et al., 2007), shoot fresh weight, shoot dry weight, root fresh weight, root dry weight, chlorophyll and carotenoid content were recorded. The estimation of chlorophyll $\mathrm{a}, \mathrm{b}$ content was determined according to Maclachlan and Zalik (1963):

$$
\begin{aligned}
& \text { Chlorophyll } \mathrm{a}=\frac{(12.3 \times \text { OD } 663 \mathrm{a}-0.86 \times \text { OD } 645 a)}{\mathrm{d} \times 1000 \times \mathrm{W}} \times \mathrm{V} \\
& \text { Chlorophyll } \mathrm{b}=\frac{(19.3 \times \text { OD } 645 \mathrm{a}-0.86 \times \text { OD } 663 \mathrm{a})}{\mathrm{d} \times 1000 \times \mathrm{W}} \times \mathrm{V} \\
& \text { Total Chlorophyll }=\frac{(20.2 \times \text { OD } 645)+(8.02 \times \text { OD663 }) \times \mathrm{V}}{\mathrm{d} \times 1000 \times \mathrm{W}}
\end{aligned}
$$

The estimation of total carotenoids was done according to Ayvaz et al. (2012):

Total carotenoid $(\mathrm{mg}) / \mathrm{g}$ tissue $=4.07 \times\left(\mathrm{OD}_{450}\right)-(0.0435$

$$
\left.\times \mathrm{Chl}_{\mathrm{a}}\right)+\left(0.367 \times \mathrm{Chl}_{\mathrm{b}}\right)
$$

Statistical analysis. Data were analyzed for significant mean differences using two-way analysis of variance (ANOVA). Means were separated using Duncan's multiple range test (DMRT; $P=0.05$ ) using SPSS software.

\section{Results}

Isolation and screening of bacterial isolates. In this work, a total of 24 bacteria were isolated from different plant rhizosphere soils from eight agro- ecological zones (AEZ) of Bangladesh (Table 1). The isolates varied in size, shape, elevation and pigment production capacity. These isolates were evaluated for their antagonistic and stress tolerance capacity.

In vitro antagonistic potential of isolated bacteria against Fusarium oxysporum. In PDA medium growth inhibition was found to range from 0.00 to $87.66 \%$ after 
Table 2. In vitro biocontrol activity of bacterial isolates against Fusarium oxysporum

\begin{tabular}{|c|c|c|c|c|c|}
\hline Test isolates & $\begin{array}{l}\text { Radial growth of the } \\
\text { pathogen }(\mathrm{mm})\end{array}$ & $\begin{array}{l}\text { Inhibition over } \\
\text { control }(\%)\end{array}$ & Test isolates & $\begin{array}{l}\text { Radial growth of the } \\
\text { pathogen }(\mathrm{mm})\end{array}$ & $\begin{array}{l}\text { Inhibition over } \\
\text { control }(\%)\end{array}$ \\
\hline Prju2 & $5.66 \pm 0.33^{\mathrm{ij}}$ & 79.03 & Prk1 & $8.66 \pm 0.33^{\text {gh }}$ & 67.92 \\
\hline Pjbb1 & $7.33 \pm 0.66^{\mathrm{hi}}$ & 72.85 & Prk2 & $12.33 \pm 0.88^{\mathrm{ef}}$ & 54.33 \\
\hline $\mathrm{Pbm} 3$ & $8.33 \pm 0.88^{\mathrm{gh}}$ & 69.14 & Prbo5 & $9.33 \pm 0.57^{\text {gh }}$ & 65.44 \\
\hline Pdbb & $5 \pm 1.52^{\mathrm{ij}}$ & 81.48 & Prbo4 & $10.66 \pm 0.88^{\mathrm{fg}}$ & 60.51 \\
\hline Prb1 & $3.33 \pm 0.33^{j}$ & 87.66 & Prbo & $19 \pm 0.57^{\mathrm{d}}$ & 29.62 \\
\hline Pbbb1 & $5 \pm 0.57^{\mathrm{ij}}$ & 81.48 & Prsp1 & $23.33 \pm 2.40^{\mathrm{c}}$ & 13.59 \\
\hline Pjbb5 & $13.66 \pm 0.33^{\mathrm{e}}$ & 49.4 & Prd5 & $12.66 \pm 0.33^{\mathrm{ef}}$ & 53.11 \\
\hline Prju $3 b$ & $7.33 \pm 0.33^{\mathrm{hi}}$ & 72.85 & Prju3 & $25 \pm 0.33^{c}$ & 7.40 \\
\hline Pjbb & $12.66 \pm 0.33^{\mathrm{ef}}$ & 53.11 & Prsp2 & $20 \pm 0.33^{\mathrm{d}}$ & 25.92 \\
\hline Prb2 & $12 \pm 0.57^{\mathrm{ef}}$ & 55.55 & Prsp3 & $28.33 \pm 0.88^{b}$ & - \\
\hline $\operatorname{Prd} 2$ & $7.33 \pm 0.33^{\text {hi }}$ & 72.85 & Prk3 & $33.33 \pm 0.88^{\mathrm{a}}$ & - \\
\hline Pjbb3 & $7.33 \pm 0.88^{\mathrm{hi}}$ & 72.85 & Control & $27 \pm 0.66^{b}$ & \\
\hline PrK4 & $9 \pm 0.57^{\mathrm{gh}}$ & 66.66 & & & \\
\hline
\end{tabular}

Values are the means of three replications. Means in a column with similar letter(s) are not significantly different at 0.05 level.
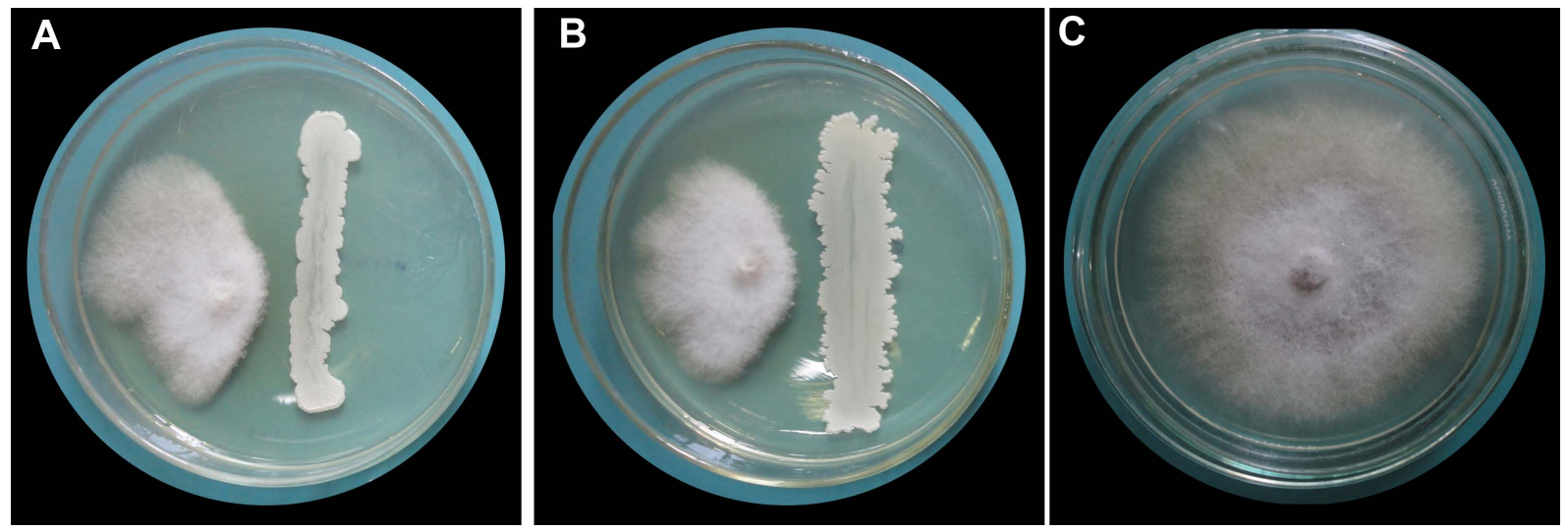

Fig. 1. Inhibition of F. oxysporum f. sp. lycopersici by two bacterial isolates (A) Bacillus methylotrophicus Prb1, and (B) Brevundimonas olei Prd2, and (C) mycelial growth of F. oxysporum in control plate.

10 days of incubation (Table 2). The bacterial isolate Prb1 exhibited maximum growth inhibition $(87.66 \%)$ against $F$. oxysporum. Two potential bacterial isolates Prb1 (87.66\%) and Prd2 (72.85\%) showing consistent antagonistic (Fig. 1) and promising stress tolerance activities (data not shown) were selected for further characterization.

Biochemical characteristics of the bacterial isolates. Several biochemical tests have been conducted to identify the biocontrol agents. The results of the biochemical tests have been summarized in Table 3 .

Molecular identification. The PCR amplification of the 16S rRNA gene resulted in products approximately $1.5 \mathrm{~kb}$ in size. The obtained 16S rRNA gene sequences were deposited in GenBank under the accession number
MH458892 and MH458893 for the isolate Prd2 and Prb1, respectively. The BLAST searches revealed that the rRNA gene of the bacterial isolate $\operatorname{Prd} 2$ has $100 \%$ identity to that of Brevundimonas olei strains and Prb1 showed 100\% identity to that of Bacillus methylotrophicus strains. The phylogenetic relation of the isolates is presented in Fig. 2. The results of molecular analyses were consistent with the morphological, biochemical and physiological traits of the isolates.

Survival profile for selected two bacterial isolates. The study showed the decrease in cfu of the isolate B. olei $\operatorname{Prd} 2$ after 28 days, while decrease in cfu was observed after 21 days in B. methylotrophicus Prblisolate (Table 4). It can be concluded that biocontrol agent $\operatorname{Prd} 2$ selected in this study can be preserved efficiently at least for 28 days at $28^{\circ} \mathrm{C}$. 
Table 3. Biochemical and physiological characteristics of two biocontrol agents

\begin{tabular}{|c|c|c|c|}
\hline \multirow{2}{*}{ No. } & \multirow{2}{*}{ Test name } & \multicolumn{2}{|c|}{ Bacterial strain } \\
\hline & & Prb1 & $\operatorname{Prd} 2$ \\
\hline 1. & Gram reaction & + & - \\
\hline & Oxidase test & + & + \\
\hline & Catalase test & + & + \\
\hline & Gelatin liquefaction & + & + \\
\hline & Nitrate reduction & - & + \\
\hline & Arginine decarboxylase activity & + & + \\
\hline & Levan formation & + & - \\
\hline & Urease test & + & + \\
\hline \multicolumn{4}{|c|}{ 9. Carbon sources utilization: } \\
\hline & Glucose & + & - \\
\hline & Maltose & - & + \\
\hline & Lactose & - & - \\
\hline & Xylose & + & + \\
\hline & Mannitol & - & - \\
\hline 10. & Starch hydrolysis test & + & + \\
\hline 11. & Protease activity & - & + \\
\hline 12. & Cellulase activity & - & + \\
\hline 13. & $\mathrm{HCN}$ production & - & + \\
\hline 14. & Siderophore production & + & + \\
\hline 15. & Growth on nitrogen free medium & - & + \\
\hline 16. & Root colonization test & + & + \\
\hline
\end{tabular}

All the tests were conducted in three replicates, ' + ' indicates positive reaction, '-' indicates negative reaction.
Table 4. Survival of selected bacterial isolates at an interval of 7 days

\begin{tabular}{crr}
\hline Days & \multicolumn{1}{c}{$\begin{array}{c}\text { Prd2 } \\
(\mathrm{cfu} / \mathrm{ml})\end{array}$} & \multicolumn{1}{c}{$\begin{array}{c}\text { Prb1 } \\
(\mathrm{cfu} / \mathrm{ml})\end{array}$} \\
\hline 0 & $1.05 \times 10^{6}$ & $1.56 \times 10^{6}$ \\
7 & $6 \times 10^{6}$ & $14 \times 10^{6}$ \\
14 & $5.2 \times 10^{7}$ & $8.8 \times 10^{7}$ \\
21 & $1.38 \times 10^{8}$ & $9 \times 10^{7}$ \\
28 & $1.65 \times 10^{8}$ & $3 \times 10^{6}$ \\
35 & $7.4 \times 10^{7}$ & - \\
\hline
\end{tabular}

Role of siderophore and iron deprivation in the in vitro inhibition of $F$. oxysporum. In the in vitro study aiming at whether this antagonistic effect was caused by the siderophore mechanism or not, the selected two bacterial isolates grown in iron-deprived and iron added medium at different ferric ion concentrations (Table 5). Siderophore mediated inhibition of fungal growth ranged from of 56.95 to $59.75 \%$ in the absence of $\mathrm{FeCl}_{3}$ whereas the inhibition percentage ranged from 2.57 to $71.62 \%$ in presence of $\mathrm{FeCl}_{3}$. At $100 \mu \mathrm{M} \mathrm{FeCl}_{3}$, the two isolates induced the maximum inhibition.

Compatibility test. Results showed that none of the bacterial isolates (B. methylotrophicus $\operatorname{Prb} 1$ and B. olei $\operatorname{Prd} 2)$ inhibited $B$. subtilis, $T$. harzianum and $T$. reesei in any of the plates; all the two bacterial isolates were compatible (data not shown).
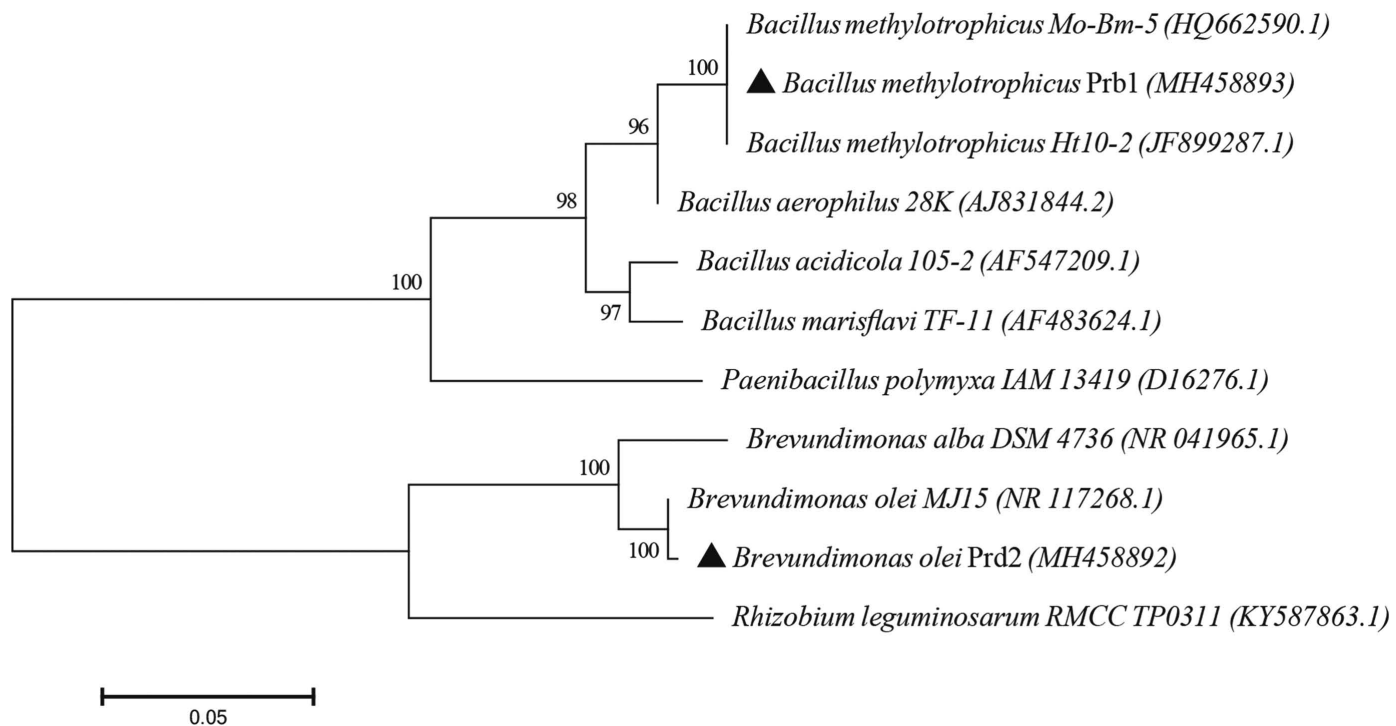

Fig. 2. Phylogenetic tree showing position of the biocontrol agents $(\boldsymbol{\Delta})$ used in this study. The 16S rDNA sequences were aligned with the ClustalW and the tree was constructed with the maximum likelihood method based on the Tamura-Nei model integrated in the MEGA7 software. The GenBank accession numbers of the DNA sequences are shown in parentheses. 
Table 5. Effect of concentration of ferric chloride on the mycelial growth (mm) of Fusarium oxysporum

\begin{tabular}{ccccc}
\hline & \multicolumn{4}{c}{ Different concentration of ferric ion } \\
\cline { 2 - 5 } Bacterial & Mycelial & Mycelial & Mycelial & Mycelial \\
isolates & $\begin{array}{c}\text { growth } \\
(0 \mu \mathrm{M})\end{array}$ & $\begin{array}{c}\text { growth } \\
(50 \mu \mathrm{M})\end{array}$ & $\begin{array}{c}\text { growth } \\
(70 \mu \mathrm{M})\end{array}$ & $\begin{array}{c}\text { growth } \\
(100 \mu \mathrm{M})\end{array}$ \\
\hline Prb1 & $9.66^{\mathrm{b}}$ & $25.33^{\mathrm{ab}}$ & $24.00^{\mathrm{a}}$ & $10.66^{\mathrm{b}}$ \\
Prd2 & $10.33^{\mathrm{b}}$ & $10.66^{\mathrm{c}}$ & $7.66^{\mathrm{b}}$ & $11.33^{\mathrm{b}}$ \\
Control & $23.33^{\mathrm{a}}$ & $26.00^{\mathrm{a}}$ & $26.66^{\mathrm{a}}$ & $27.66^{\mathrm{a}}$ \\
\hline
\end{tabular}

Values are the means of three replications. Means in a column with similar letter(s) are not significantly different at 0.05 level.

Table 6. Effect of bacterial isolates on the seed germination of two cultivars (Pusa Ruby and Ratan) of tomato

\begin{tabular}{ccc}
\hline \multirow{2}{*}{$\begin{array}{c}\text { bacterial } \\
\text { isolate }\end{array}$} & \multicolumn{2}{c}{ Seed germination $(\%)$} \\
\cline { 2 - 3 } & Pusa Ruby & Ratan \\
\hline Prd2 & $81^{\mathrm{b}}$ & $79^{\mathrm{a}}$ \\
Prb1 & $84^{\mathrm{b}}$ & $85^{\mathrm{a}}$ \\
Control & $96^{\mathrm{a}}$ & $78^{\mathrm{a}}$ \\
\hline
\end{tabular}

Values are the mean of three replications. Means in a column with similar letter(s) are not significantly different at 0.05 level.

Germination Percentage (GP) and seedling vigor. Germination of tomato seeds recorded in germination test varied among the cultivars (Table 6). Bacterization of tomato seeds (cv. Ratan), there was no significative difference observed between treatments. Whereas, tomato seeds (cv. Pusa Ruby), bacterized seeds showed significant difference over the control and the two isolates have the same effect. There was an improvement in seedling vigor upon addition of bacterial isolates to tomato seeds. Under laboratory

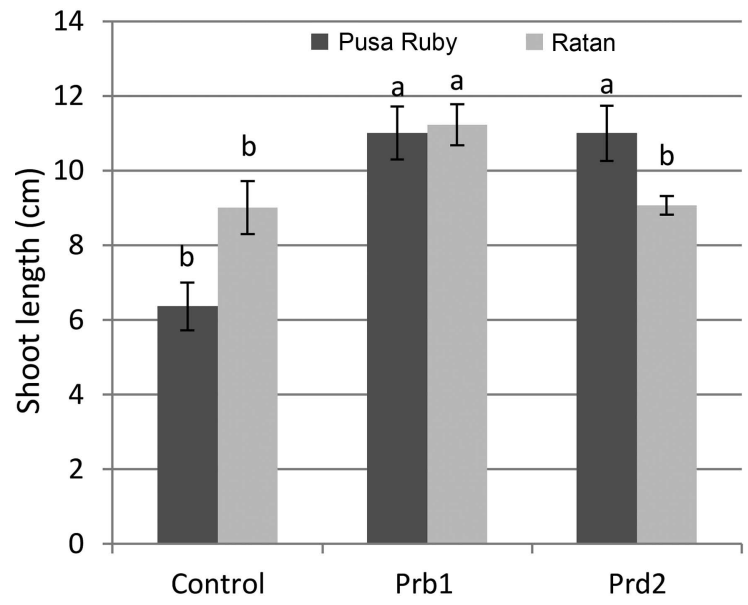

Fig. 3. The effect of bacterization of tomato seeds with two biocontrol agents on shoot length of tomato seedlings. Data are mean of three replications. Bars indicate standard error of the mean.

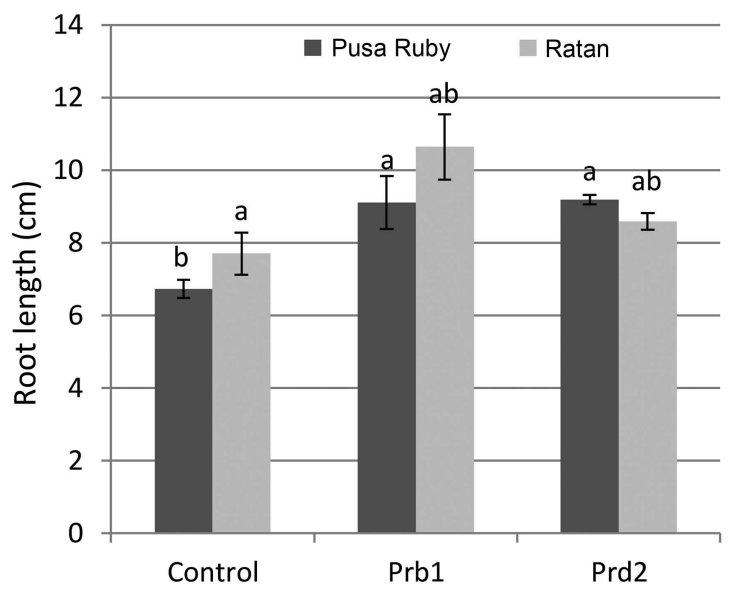

Fig. 4. The effect of bacterization of tomato seeds with two biocontrol agents on root length of tomato seedlings. Data are mean of three replications. Bars indicate error of the mean.

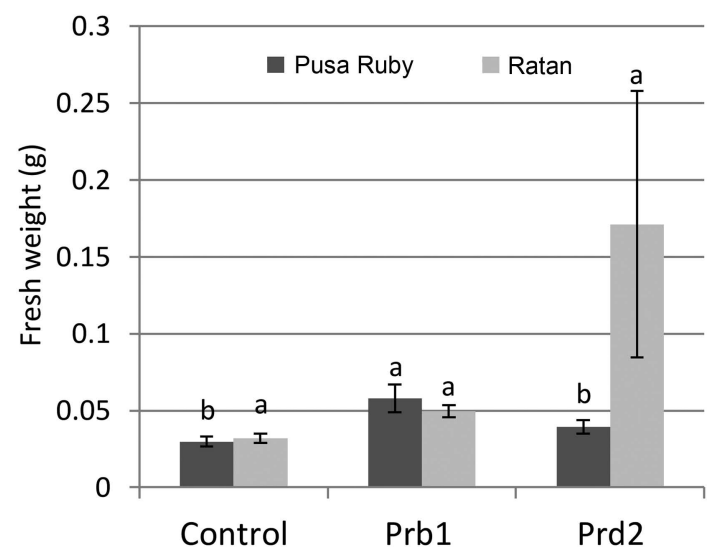

Fig. 5. The effect of bacterization of tomato seeds with two biocontrol agents on the fresh weight of tomato seedlings. Data are mean of three replications. Bars indicate standard error of the mean.

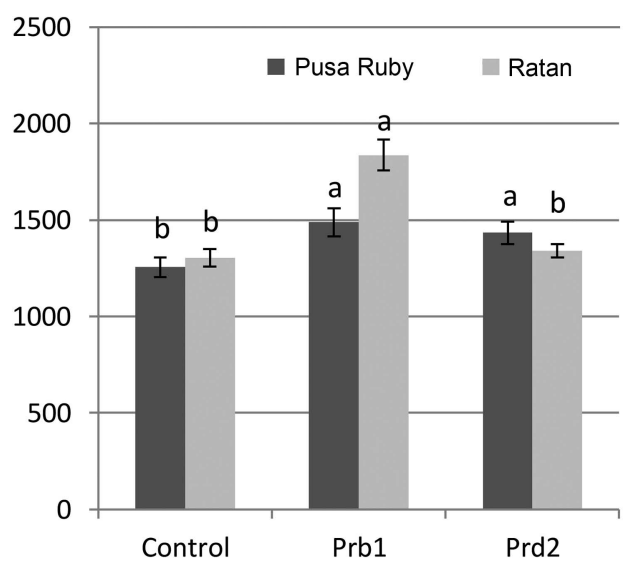

Fig. 6. The effect of bacterization of tomato seeds with two biocontrol agents on vigor index of tomato seedlings. Data are mean of three replications. Bars indicate standard error of the mean. 
Table 7. The average disease incidence and biocontrol efficacy in controlling Fusarium wilt of treated tomato plant with rhizobacterial isolates in year 2015-16 and 2016-17

\begin{tabular}{|c|c|c|c|c|c|c|}
\hline Treatments & Bacterial inocula & $\begin{array}{c}\text { Disease incidence } \\
2015-16\end{array}$ & $\begin{array}{l}\text { Biocontrol } \\
\text { efficacy }(\%)\end{array}$ & $\begin{array}{c}\text { Disease incidence } \\
2016-17\end{array}$ & $\begin{array}{l}\text { Biocontrol } \\
\text { efficacy }(\%)\end{array}$ & $\begin{array}{l}\text { Biocontrol efficacy } \\
\text { (Mean of } 2 \text { years) }\end{array}$ \\
\hline \multirow[t]{3}{*}{ Pusa Ruby } & $\begin{array}{l}\text { Un-inoculated } \\
\text { (Control inoculated with } F \text {. } \\
\text { oxysporum f. sp. lycpeorsici) }\end{array}$ & $41.66 \pm 2.30^{\mathrm{a}}$ & & $41.66 \pm 0.58^{\mathrm{a}}$ & & \\
\hline & $\operatorname{Prd} 2$ & $20.83 \pm 3.17^{\mathrm{c}}$ & 50 & $25 \pm 4.04^{\mathrm{b}}$ & 39.99 & 44.99 \\
\hline & Prb1 & $29.16 \pm 0.58^{b}$ & 30 & $33.33 \pm 2.51^{\mathrm{ab}}$ & 19.99 & 24.99 \\
\hline \multirow[t]{3}{*}{ Ratan } & $\begin{array}{l}\text { Un-inoculated } \\
\text { (Control inoculated with } F \text {. } \\
\text { oxysporum f. sp. lycpeorsici) }\end{array}$ & $42.33 \pm 4.16^{\mathrm{a}}$ & & $58.33 \pm 3.05^{\mathrm{a}}$ & & \\
\hline & $\operatorname{Prd} 2$ & $24.99 \pm 3.05^{\mathrm{b}}$ & 40.97 & $33.33 \pm 6.65^{\mathrm{bc}}$ & 42.85 & 41.91 \\
\hline & Prb1 & $33.33 \pm 2.64^{\mathrm{ab}}$ & 21.26 & $25 \pm 3.00^{\mathrm{c}}$ & 57.14 & 39.20 \\
\hline
\end{tabular}

Values are the means $( \pm$ SEM) of three replications. Means in a column with similar letter(s) are not significantly different at 0.05 level according to Duncan Multiple Range Test.

conditions, all the isolates showed higher mean root length, higher mean shoot length, and vigor index with respect to control (Fig. 3-6). The isolate B. methylotrophicus Prb1 caused the maximum increase $(11.22 \mathrm{~cm})$ of shoot length in the Ratan cultivar, while in Pusa Ruby the two isolates have the same effect in shoot length $(11 \mathrm{~cm})$. Addition of the isolate $B$. olei $\operatorname{Prd} 2$ recorded the maximum increase of root length $(9.18 \mathrm{~cm})$ in Pusa Ruby, while addition of the isolate Prb1 recorded the maximum increase of root length $(10.64 \mathrm{~cm})$ in Ratan cultivar. Among the isolates, the isolate $B$. methylotrophicus Prb1 recorded the highest fresh weight in Pusa Ruby, while addition of the isolate $B$. olei Prd2 recorded the highest fresh weight in Ratan cultivar. Highest vigor index was observed in both the cultivars by the addition of the isolate Prb1.

Biocontrol potential of selected bacterial isolates. In this study, disease incidence was reduced to different levels depending on the bacterial isolates. Tomato plants treated with the bacterial isolates looked healthy and showed a lower incidence of wilt disease in both of the growing seasons (Table 7). Treatment of tomato cultivar Pusa ruby with the isolate $B$. olei $\operatorname{Prd} 2$ reduced the disease incidence by $50 \%$ in $2015-16$ and $39.99 \%$ in 2016-17 cropping seasons. Whereas treatment of tomato cultivar Ratan with the same isolate ( $\operatorname{Prd} 2)$ reduced the disease incidence by $40.97 \%$ in 2015-16 and $42.85 \%$ in 2016-17 cropping seasons.

Using B. methylotrophicus Prb1and B. olei Prd2 isolates,

Table 8. Effect of bacterial isolates on growth parameters of tomato (cv. Pusa Ruby)

\begin{tabular}{|c|c|c|c|c|c|c|}
\hline \multirow{2}{*}{ Growth parameters } & \multicolumn{3}{|c|}{ Bacterial inoculums (2015-16) } & \multicolumn{3}{|c|}{ Bacterial inoculums (2016-17) } \\
\hline & Uninoculated & $\operatorname{Prd} 2$ & Prb1 & Uninoculated & $\operatorname{Prd} 2$ & Prb1 \\
\hline Height (cm) & $52 \pm 2.00^{\mathrm{b}}$ & $66 \pm 7.57^{\mathrm{ab}}$ & $75 \pm 2.51^{\mathrm{a}}$ & $53 \pm 1.52^{\mathrm{b}}$ & $62 \pm 1.52^{\mathrm{ab}}$ & $69 \pm 4.61^{a}$ \\
\hline Leaf area $\left(\mathrm{cm}^{2}\right)$ & $150 \pm 3.93^{b}$ & $234 \pm 5.29^{\mathrm{a}}$ & $163.8 \pm 4.10^{\mathrm{b}}$ & $396 \pm 5.34^{\mathrm{a}}$ & $336 \pm 5.95^{\mathrm{a}}$ & $368 \pm 6.06^{\mathrm{a}}$ \\
\hline Leaves no./plant & $44 \pm 3.05^{\mathrm{c}}$ & $73 \pm 4.50^{\mathrm{a}}$ & $59 \pm 2.64^{\mathrm{b}}$ & $20 \pm 1.15^{\mathrm{b}}$ & $18 \pm 2.64^{b}$ & $30 \pm 1.15^{\mathrm{a}}$ \\
\hline Root length (cm) & $11.1 \pm 2.08^{\mathrm{b}}$ & $24.5 \pm 1.15^{\mathrm{a}}$ & $22.2 \pm 2.00^{\mathrm{a}}$ & $15 \pm 2.30^{\mathrm{a}}$ & $12.6 \pm 2.51^{\mathrm{a}}$ & $16 \pm 2.51^{\mathrm{a}}$ \\
\hline Root fresh weight (g/plant) & $8.25 \pm 0.58^{\mathrm{ab}}$ & $12.08 \pm 2.88^{\mathrm{a}}$ & $4.10 \pm 1.00^{\mathrm{c}}$ & $3.59 \pm 0.58^{\mathrm{c}}$ & $9.95 \pm 1.15^{\mathrm{b}}$ & $22.82 \pm 0.58^{\mathrm{a}}$ \\
\hline Shoot fresh weight (g/plant) & $37.45 \pm 3.46^{\mathrm{b}}$ & $107.21 \pm 5.77^{\mathrm{a}}$ & $117.10 \pm 4.72^{\mathrm{a}}$ & $61.25 \pm 4.01^{\mathrm{a}}$ & $59.02 \pm 2.08^{\mathrm{a}}$ & $59.15 \pm 6.35^{\mathrm{a}}$ \\
\hline Root dry weight (g/plant) & $4.23 \pm 0.58^{\mathrm{a}}$ & $3.05 \pm 1.00^{\mathrm{a}}$ & $1.16 \pm 0.58^{\mathrm{a}}$ & $2.6 \pm 0.58^{\mathrm{b}}$ & $7.81 \pm 0.58^{\mathrm{b}}$ & $17.41 \pm 2.64^{\mathrm{a}}$ \\
\hline Shoot dry weight (g/plant) & $6.09 \pm 1.00^{\mathrm{b}}$ & $15.68 \pm 1.52^{\mathrm{a}}$ & $18.01 \pm 0.58^{\mathrm{a}}$ & $31.25 \pm 4.93^{\mathrm{a}}$ & $18.56 \pm 5.29^{\mathrm{a}}$ & $15.38 \pm 4.04^{\mathrm{a}}$ \\
\hline Chlorophyll a (mg/g) & $1.397 \pm 1.00^{\mathrm{a}}$ & $1.550 \pm 0.577^{\mathrm{a}}$ & $1.899 \pm 0.00^{\mathrm{a}}$ & $1.07 \pm 0.577^{\mathrm{a}}$ & $1.258 \pm 0.58^{\mathrm{a}}$ & $1.661 \pm 1.00^{\mathrm{a}}$ \\
\hline Chlorophyll b (mg/g) & $0.885 \pm 0.00^{\mathrm{a}}$ & $0.906 \pm 0.43^{\mathrm{a}}$ & $1.074 \pm 1.00^{\mathrm{a}}$ & $0.579 \pm 0.062^{\mathrm{a}}$ & $0.608 \pm 0.58^{\mathrm{a}}$ & $0.832 \pm 0.00^{\mathrm{a}}$ \\
\hline Total chlorophyll (mg/g) & $1.971 \pm 0.58^{\mathrm{a}}$ & $2.126 \pm 1.52^{\mathrm{a}}$ & $2.541 \pm 0.58^{\mathrm{a}}$ & $1.215 \pm 0.58^{\mathrm{a}}$ & $1.572 \pm 0.58^{\mathrm{a}}$ & $1.909 \pm 1.00^{\mathrm{a}}$ \\
\hline Carotenoids $(\mathrm{mg} / \mathrm{g})$ & $5.572 \pm 2.08^{\mathrm{a}}$ & $5.572 \pm 1.15^{\mathrm{a}}$ & $7.494 \pm 1.52^{\mathrm{a}}$ & $4.061 \pm 1.15^{\mathrm{ab}}$ & $4.942 \pm 0.58^{\mathrm{ab}}$ & $6.690 \pm 1.15^{\mathrm{a}}$ \\
\hline
\end{tabular}

Values are the means $( \pm$ SE) of three replications. Means in a column with similar letter(s) are not significantly different at 0.05 level according to Duncan Multiple Range Test. 
Table 9. Effect of bacterial isolates on growth parameters of tomato (cv. Ratan)

\begin{tabular}{|c|c|c|c|c|c|c|}
\hline \multirow{2}{*}{ Growth parameters } & \multicolumn{3}{|c|}{ Bacterial inoculums (2015-16) } & \multicolumn{3}{|c|}{ Bacterial inoculums (2016-17) } \\
\hline & Uninoculated & $\operatorname{Prd} 2$ & Prb1 & Uninoculated & $\operatorname{Prd} 2$ & Prb1 \\
\hline Height (cm) & $61 \pm 4.04^{\mathrm{b}}$ & $83 \pm 2.51^{\mathrm{a}}$ & $62 \pm 5.29^{b}$ & $60 \pm 1.73^{\mathrm{bc}}$ & $64 \pm 3.05^{\mathrm{ab}}$ & $56 \pm 2.64^{c}$ \\
\hline Leaf area $\left(\mathrm{cm}^{2}\right)$ & $215 \pm 8.54^{b}$ & $384 \pm 5.68^{\mathrm{a}}$ & $222 \pm 2.15^{\mathrm{b}}$ & $486 \pm 7.81^{\mathrm{a}}$ & $450 \pm 5.13^{\mathrm{a}}$ & $415 \pm 8.80^{\mathrm{a}}$ \\
\hline Leaves no./plant & $37 \pm 4.16^{\mathrm{a}}$ & $37 \pm 8.18^{\mathrm{a}}$ & $45 \pm 0.57^{\mathrm{a}}$ & $29 \pm 1.52^{\mathrm{a}}$ & $13 \pm 2.00^{\mathrm{b}}$ & $28 \pm 4.35^{\mathrm{a}}$ \\
\hline Root length (cm) & $20 \pm 1.00^{\mathrm{a}}$ & $20.2 \pm 3.05^{\mathrm{a}}$ & $20 \pm 1.52^{\mathrm{a}}$ & $14.9 \pm 2.51^{\mathrm{a}}$ & $11 \pm 2.51^{\mathrm{a}}$ & $14 \pm 1.73^{\mathrm{a}}$ \\
\hline Root fresh weight (g/plant) & $3.25 \pm 0.58^{\mathrm{c}}$ & $16.99 \pm 1.00^{\mathrm{a}}$ & $3.95 \pm 0.58^{\mathrm{b}}$ & $17.5 \pm 2.64^{\mathrm{a}}$ & $9.6 \pm 1.52^{\mathrm{b}}$ & $6.59 \pm 1.15^{\mathrm{b}}$ \\
\hline Shoot fresh weight (g/plant) & $40.4 \pm 1.70^{\mathrm{a}}$ & $48.10 \pm 4.93^{\mathrm{a}}$ & $42.47 \pm 7.81^{\mathrm{a}}$ & $52.32 \pm 5.56^{\mathrm{a}}$ & $62.63 \pm 4.04^{\mathrm{a}}$ & $65.46 \pm 6.80^{\mathrm{a}}$ \\
\hline Root dry weight (g/plant) & $1.43 \pm 0.58^{\mathrm{b}}$ & $8.74 \pm 1.52^{\mathrm{a}}$ & $2.39 \pm 1.73^{\mathrm{b}}$ & $8.25 \pm 2.00^{\mathrm{a}}$ & $6.09 \pm 1.52^{\mathrm{a}}$ & $4.4 \pm 1.15^{\mathrm{a}}$ \\
\hline Shoot dry weight (g/plant) & $7.042 \pm 1.15^{\mathrm{a}}$ & $15.71 \pm 3.51^{\mathrm{a}}$ & $8.97 \pm 2.64^{\mathrm{a}}$ & $9.71 \pm 1.73^{\mathrm{a}}$ & $28.89 \pm 9.01^{\mathrm{a}}$ & $22.54 \pm 2.08^{\mathrm{a}}$ \\
\hline Chlorophyll a (mg/g) & $1.211 \pm 1.73^{\mathrm{a}}$ & $1.670 \pm 0.58^{\mathrm{a}}$ & $1.745 \pm 0.58^{\mathrm{a}}$ & $1.366 \pm 0.58^{\mathrm{a}}$ & $1.366 \pm 1.00^{\mathrm{a}}$ & $0.832 \pm 0.00^{\mathrm{a}}$ \\
\hline Chlorophyll b (mg/g) & $0.737 \pm 0.00^{\mathrm{a}}$ & $0.959 \pm 0.13^{\mathrm{a}}$ & $1.022 \pm 1.00^{\mathrm{a}}$ & $0.652 \pm 0.00^{\mathrm{a}}$ & $0.366 \pm 0.170^{\mathrm{a}}$ & $0.452 \pm 0.00^{\mathrm{a}}$ \\
\hline Total chlorophyll (mg/g) & $1.676 \pm 0.58^{\mathrm{a}}$ & $2.226 \pm 1.15^{\mathrm{a}}$ & $2.373 \pm 1.52^{\mathrm{a}}$ & $1.698 \pm 0.58^{\mathrm{a}}$ & $0.925 \pm 1.00^{\mathrm{a}}$ & $1.143 \pm 0.58^{\mathrm{a}}$ \\
\hline Carotenoids $(\mathrm{mg} / \mathrm{g})$ & $5.044 \pm 1.15^{\mathrm{a}}$ & $6.604 \pm 1.52^{\mathrm{a}}$ & $7.060 \pm 0.577^{\mathrm{a}}$ & $5.662 \pm 1.00^{\mathrm{a}}$ & $2.937 \pm 1.15^{\mathrm{ab}}$ & $3.931 \pm 0.58^{\mathrm{ab}}$ \\
\hline
\end{tabular}

Values are the means ( \pm SEM) of three replications. Means in a column with similar letter(s) are not significantly different at 0.05 level.

growth promotion assays were performed in two successive years. The magnitude of growth promotion varied among the bacterial isolates and tomato cultivars. Results of this experiment showed (Table 8,9) that bacterial isolates have stimulated plant growth under pot conditions. Highest biomass increase was recorded in treatment with $B$. methylotrophicus Prblisolate. The effect of bacterial inoculation showed that inoculation of bacterial isolates slightly increased chlorophyll and carotenoid contents.

\section{Discussion}

The agro-ecological system and constituents of plant root exudates determine the type and density of microbial population in a given crop production system (Van Overbeek et al., 1997). Beneduzi et al. (2008) also stated that rhizospheric microbial community is determined by both soil characteristics and plant species. So, the present study was conducted to explore the potentiality of bacteria isolated from the rhizosphere soil of different agro- ecological zones (AEZs) of Bangladesh for biocontrol of Fusarium wilt of tomato as well as plant growth promotion.

Out of 24 randomly selected isolates, 22 (91.66\%) showed different level of inhibitory activity against $F$. oxysporum. In dual cultures all bacterial isolates showed variations in inhibition of mycelial growth of $F$. oxysporum. Several workers also reported similar effects against numerous fungi including Fusarium species (Khan and Zaidi, 2002; Sivamani and Gnanamanickam, 1988). In the present study, variable antifungal activity of different isolates could be attributed to the quantity and effectiveness of the antimicrobials produced by the isolates.
The selected two biocontrol isolates were identified by morphological, cultural, biochemical and molecular characteristics. The isolates Prb1 and Prd2 were identified as B. methylotrophicus and B. olei, respectively. Although the presence of $B$. olei has been reported from various region of the world (Fan et al., 2016; Lee et al., 2010), no literature on the presence of $B$. olei in Bangladesh soil exists. Hence, this is the first report of $B$. olei from Bangladesh.

In present study it was found that the selected bacterial isolates showed antagonist activity against $F$. oxysporum along with one or more lytic enzyme production. The addition of $\mathrm{FeCl}_{3}$ to Kings $\mathrm{B}$ at 50 and $70 \mu \mathrm{M}$ eliminated the inhibitory effect of siderophores produced by bacterial isolates against $F$. oxysporum. This indicated siderophore mediation along with antifungal metabolites. Reduction of antagonism by the addition of iron indicated that siderophores and other defensive metabolites were inhibitory to fungal growth and showed a cumulative effect of different defensive mechanisms (Bultrey and Gheysen, 2000). Suryakala et al. (2004) reported that siderophores exerted maximum impact on $F$. oxysporum than on Alternaria sp. and Colletotrichum capsici. The selected two rhizobacterial isolates were tested for their cyanogenic activity and the result revealed that only B. olei $\operatorname{Prd} 2$ isolate produced $\mathrm{HCN}$. Hydrogen cyanide production by rhizospheric bacteria is beneficial from the biocontrol point of view. This volatile metabolite is thought to play a major role in biological control of some soil borne diseases (Siddiqui et al., 2006). Among the isolates, only isolate $B$. ole $\operatorname{Prd} 2$ was able to grow in the Norris $\mathrm{N}$-free agar medium indicating that this isolate is probably able to utilize the atmospheric nitrogen. Kumar and Gera (2014) reported that Brevundimonas sp. 
isolated from sugarcane rhizospheric soil showed nitrogenfixing potential. Gulati et al. (2011) also reported nitrogenase activity by acetylene reduction assay of the strains of $B$. bullata. Both the isolates ( $\operatorname{Prb} 1$ and $\operatorname{Prd} 2$ ) showed positive for root colonization. Results of the study showed that none of these two isolates inhibited B. subtilis, T. harzianum and $T$. reesei. Study of these interactions is extremely important as an effective means for their integration with the disease management practices (Belkar and Gade, 2012) and correlating their specific role in the host-pathogen other microorganisms interactions (Mishra et al., 2011).

In the present study, Brevundimonas olei and Bacillus methylotrophicus were able to significantly enhance all measured plant growth parameters. There was variation in germination and seed vigor index in both the cultivars with the bacterial treatments when compared to controls indicating that microbial inoculants can enhance seed vigor index. Similar effects of the rhizobacteria were also reported by other authors in tomato (Murthy et al., 2014) and pearl millet (Niranjan et al., 2003).

Disease incidence was reduced to different levels depending on the bacterial isolates and was estimated up to 57.14 compared to control on the tomato plants. The use of bioagents was reported quite effective to control Fusarium wilt disease in tomato (Freeman et al., 2002). In the present study, B. methylotrophicus Prb1 showed highest in vitro antagonistic activity but in the pot culture isolate $B$. olei $\operatorname{Prd} 2$ showed slightly higher disease inhibition than Prb1. This may be due to increased fitness of the isolate $B$. olei $\operatorname{Prd} 2$ to the biotic and abiotic factors of the experimental field. Wei et al. (2017) stated that microbe-microbe interactions are very sensitive to several abiotic and biotic factors such as environmental temperature, productivity and microbial community composition, which could affect biocontrol outcomes by changing the strength of species interactions. In the experiment, application of $B$. olei reduced 44.99 and $41.91 \%$ of disease incidence of two tomato cultivar Pusa Rubi and Ratan, respectively as compared to infected untreated control. Application of B. methylotrophicus also reduced percentage of disease incidence of tomato plants as compared to infected untreated control. Thus, these treatments improved plant health through reducing wilt symptoms. Our results also corroborated with the findings of other researchers (Almoneafy et al., 2012; Ge et al., 2016).

The growth responses of test plant tomato to rhizobacterial treatments varied significantly with the cultivar-type and isolate type. The variations in plant growth promotion among the isolates are attributed to their individual competencies (Geetha et al., 2014). The selected isolates significantly increased root length, shoot length and exhibited biomass increase of treated tomato plants compared to control plant. Present results were in agreement with those reported by Mezeal (2014), who reported that the growth parameters of tomato plants were increased with the addition of $B$. subtilis and $P$. fluorescens to the soil with $F$. oxysporum under field condition.

Extensive rooting was observed in bacteria-treated tomato plants compared with the control. The rooting might have contributed towards the resistance, growth and development of the plant. According to Raj et al. (2003), the possible mechanisms could be the larger and healthier root system leading to improved uptake of water and nutrients. In respect of $B$. methylotrophicus our results corroborated with the findings of Ambawade and Pathade (2015) and Ge et al. (2016). In respect of Brevundimonas species, similar improvement of growth parameters has been reported in wheat (Rana et al., 2011) and Bt-cotton (Kumar and Gera, 2014). Changes in plant pigments of two cultivars of tomato during tomato growth season 2015-16 and 2016-17 was also observed. The results shown that bacterial treatments increased chlorophyll and carotenoid contents in tomato plants compared to the untreated control. Similar pattern of influence was also reported in other studies (Lamsal et al., 2013). Application of rhizobacterial isolates might have affected the production of these biochemicals in plants. These plants mediated mechanism had been proposed by researchers as regulating force behind plant growth promotion by PGP bacterial strains (Silva et al., 2003).

In conclusion, among the 24 rhizobacterial isolates tested, we have found two potential indigenous soil-borne antagonists, Brevundimonas olei $\operatorname{Prd} 2$ and Bacillus methylotrophicus Prb1. The selected rhizobacterial isolates are capable of reducing Fusarium wilt disease under local agroclimatic conditions of Bangladesh. This study reports new native isolates of $B$. ole $i$ with potential to control not only Fusarium wilt disease but also promoted growth of tomato plant. Therefore, these bacteria could be used at the field level to control the $F$. oxysporum. However, further studies on different formulations for practically implementing such propositions will be required.

\section{References}

Akköprü, A. and Demir, S. 2005. Biological control of Fusarium wilt in tomato caused by Fusarium oxysporum f.sp. lycopersici by AMF Glomus intraradices and some rhizobacteria. $J$. Phytopathol. 153:544-550.

Almoneafy, A., Xie, G. L., Tian, W. X., Xu, L. H., Zhang, G. Q. and Ibrahim, M. 2012. Characterization and evaluation of 
Bacillus isolates for their potential plant growth and biocontrol activities against tomato bacterial wilt. Afr. J. Biotechnol. 11:7193-7201.

Altschul, S. F., Gish W., Miller, W., Myers, E. W. and Lipman, D. J. 1990. Basic local alignment search tool. J. Mol. Biol. 215:403-410.

Ambawade, M. S. and Pathade, G. R. 2015. Production of gibberellic acid by Bacillus siamensis BE 76 isolated from banana plant (Musa spp.). Int. J. Sci. Res. 4:394-398.

Ayvaz, M., Koyuncu, M., Güven, A. and Fagerstedt, K. V. 2012. Does boron affect hormone levels of barley cultivars? Eurasia. J. Biosci. 6:113-120.

Bahig, A. E., Aly, E. A., Khaled, A. A. and Amel, K. A. 2008. Isolation, characterization and application of bacterial population from agricultural soil at Sohag Province, Egypt. Mal. J. Microbiol. 4:42-50.

Bakker, A. W. and Schippers, B. 1987. Microbial cyanide production in the rhizosphere in relation to potato yield reduction and Pseudomonas spp. mediated plant growth stimulation. Soil Biol. Biochem. 19:451-457.

Belkar, Y. K. and Gade, R. M. 2012. Compatibility of fluorescent Pseudomonads with beneficial microorganisms. J. Plant Dis. Sci. 7:267-268.

Beneduzi, A., Peres, D., Vargas, L. K., Bodanese-Zanettini, M. H. and Passaglia, L. M. P. 2008. Evaluation of genetic diversity and plant growth promoting activities of nitrogen-fixing Bacilli isolated from rice fields in south Brazil. Appl. Soil Ecol. 39:311-320.

Bergey, D. H. and Holt, J. G. 2000. Bergey's manual of determinative bacteriology. 9th ed. Lippincott Williams \& Wilkins, Philadelphia, USA. 787 pp.

Bhakthavatchalu, S., Shivakumar, S. and Sullia, S. B. 2013. Characterization of multiple plant growth promotion traits of Pseudomonas aeruginosa FP6, a potential stress tolerant biocontrol agent. Ann. Biol. Res. 4:214-223.

Bultreys, A. and Gheysen, I. 2000. Production and comparison of peptide siderophores from strains of distantly related pathovars of Pseudomonas syringae and Pseudomonas viridiflava LMG 2352. Appl. Environ. Microbiol. 66:325-331.

Carmassi, G., Incrocci, L., Incrocci, G. and Pardossi, A. 2007. Non-destructive estimation of leaf area in (Solanum lycopersicum L.) and gerbera (Gerbera jamesonii H. bolus). Agr. Med. 137:172-176.

Chookietwattana, K. and Maneewan, K. 2012. Selection of efficient salt-tolerant bacteria containing ACC deaminase for promotion of tomato growth under salinity stress. Soil Environ. 31:30-36.

Fan, Z.-U., Miao, C.-P., Qiao, X.-G., Zheng, Y.-K., Chen, H.-H., Chen, Y.-W., Xu, L.-H., Zhao, L.-X. and Guan, H.-L. 2016. Diversity, distribution, and antagonistic activities of rhizobacteria of Panax notoginseng. J. Ginseng Res. 40:97-104.

Freeman, S., Zveibil, A., Vintal, H. and Maymon, M. 2002. Isolation of non-pathogenic mutants of Fusarium oxysporum $\mathrm{f}$. sp. melonis for biological control of Fusarium wilts in Cucurbits.
Phytopathology 92:164-168.

Ge, B., Liu, B., Nwet, T. T., Zhao, W., Shi, L. and Zhang, K. 2016. Bacillus methylotrophicus strain NKG-1, isolated from Changbai mountain, China, has potential applications as a biofertilizer or biocontrol agent. PLOS ONE 11:e0166079.

Geetha, K., Chaitanya, K. and Bhadraiah, B. 2014. Isolation and characterization of PGPR isolates from rhizosphere soils of greengram in Warangal district of Telangana. Int. J. Pharm. Bio Sci. 5:153-163.

Gulati, A., Sood, S., Rahi, P., Thakur, R., Chauhan, S. and Chawla, I. 2011. Diversity analysis of diazotrophic bacteria associated with the roots of tea (Camellia sinensis (L.) O. Kuntze). J. Microbiol. Biotechnol. 21:545-555.

Guo, J. H., Qi, H. Y., Guo, Y. H., Ge, H. L., Gong, L. Y., Zhang, L. X. and Sun, P. H. 2004. Biocontrol of tomato wilt by growth promoting rhizobacteria. Biol. Control 29:66-72.

ISTA. 1976. International rules for seed testing. Seed Sci. Technol. 4:3-49.

ISTA. 1996. International rules for seed testing. Seed Sci. Technol. 24:211-288.

ISTA. 1999. International rules for seed testing. Seed Sci. Technol. 27:27-31.

Khalequzzaman, K. M., Jinnah, M. A., Rashid, M. A. A. M., Chowdhury, M. N. A. and Alam, M. M. 2002. Effect of Pseudomonas fluorescens in controlling bacterial wilt of tomato. Pak. J. Plant Pathol. 1:71-73.

Khan, M. S. and Zaidi, A. 2002. Plant growth promoting rhizobacteria from rhizosphere of wheat and chickpea. Ann. Plant Prot. Sci. 10:265-271.

Kumar, P., Dubey, R. C. and Maheshwari, D. K. 2012. Bacillus strains isolated from rhizosphere showed plant growth promoting and antagonistic activity against phytopathogens. Microbiol. Res. 167:493-499.

Kumar, S., Stecher, G. and Tamura, K. 2016. MEGA7: Molecular evolutionary genetics analysis version 7.0 for bigger datasets. Mol. Biol. Evol. 33:1870-1874.

Kumar, V. and Gera, R. 2014. Isolation of a multi-trait plant growth promoting Brevundimonas sp. and its effect on the growth of Bt-cotton. 3 Biotech. 4:97-101.

Lamsal, K., Kim, S. W., Kim, Y. S. and Lee, Y. S. 2013. Biocontrol of late blight and plant growth promotion in tomato using rhizobacterial isolates. J. Microbiol. Biotechnol. 23:897-904.

Lee, M., Srinivasan, S. and Kim, M. K. 2010. New taxa in Alphaproteobacteria: Brevundimonas olei sp. nov., an esteraseproducing bacterium. J. Microbiol. 48:616-622.

Maclachlan, S. and Zalik, S. 1963. Plastid structure, chlorophyll concentration and free amino-acid composition of a chlorophyll mutant of barley. Can. J. Bot. 41:1053-1062.

Malleswari, D. and Bagyanarayana, G. 2013. In vitro screening of rhizobacteria isolated from the rhizosphere of medicinal and aromatic plants for multiple plant growth promoting activities. J. Microbiol. Biotechnol. Res. 3:84-91.

Mezeal, I. A. 2014. Study biocontrol efficacy of Pseudomonas fluorescens and Bacillus subtilis against Rhizoctonia solani 
and Fusarium oxysporum causing disease in tomato. Indian J. Fund. Appl. Life Sci. 4:175-183.

Mishra, D. S., Gupta, A. K., Prajapati, C. R. and Singh, U. S. 2011. Combination of fungal and bacterial antagonists for management of root and stem rot disease of soybean. Pak. J. Bot. 43:2569-2574.

Mistry, K. K., Chatterjee, D. D. and Khair, A. 2008. Effect of compost on diseases incidence in winter tomato (Lycopersicon esculentum Mill.) under open field conditions. B. Res. Pub. J. 1:312-318.

Murthy, K. N., Uzma, F., Chitrashree and Srinivas, C. 2014. Induction of systemic resistance in tomato against Ralstonia solanacearum by Pseudomonas fluorescens. Am. J. Plant Sci. 5:1799-1811.

Naik, P. R., Raman, G., Narayanan, K. B. and Sakthivel, N. 2008. Assessment of genetic and functional diversity of phosphate solubilizing fluorescent pseudomonads isolated from rhizospheric soil. BMC Microbiol. 8:230.

Niranjan Raj, S., Deepak, S. A., Basavaraju, P., Shetty, H. S., Reddy, M. S. and Kloepper, J. W. 2003. Comparative performance of formulations of plant growth promoting rhizobacteria in growth promotion and suppression of downy mildew in pearl millet. Crop Prot. 22:579-588.

Raihan, A., Khandaker, M., Ferdous, M., Rahman, M. A., Uddin, J. and Nahiyan, M. 2016. Trichoderma suppresses pathogenic Fusarium causing tomato wilt in Bangladesh. British Microbiol. Res. J. 14:1-9.

Raj, S. N., Deepak, S. A., Basavaraju, P., Shetty, H. S., Reddy, M. S. and Kloepper, J. W. 2003. Comparative performance of formulations of plant growth promoting rhizobacteria in growth promotion and suppression of downy mildew in pearl millet. Crop Prot. 22:579-588.

Ramanathan, A., Shanmugam, V., Raguchander, T. and Samiyappan, R. 2002. Induction of systemic resistance in ragi against blast disease caused by Pseudomonas fluorescens. Ann. Plant Prot. Sci. 10:313-318.

Rana, A., Saharan, B., Joshi, M., Prasanna, R., Kumar, K. and Nain, L. 2011. Identification of multi-trait PGPR isolates and evaluating their potential as inoculants for wheat. Ann. Microbiol. 61:893-900.

Schaad, N. W., Jones, J. B. and Chun, W. 2001. Laboratory guide for the identification of plant pathogenic bacteria. 3rd ed. APS Press, St. Paul, MN, USA. 373 pp.

Shruti, K., Arun, K. and Yuvneet, R. 2013. Potential plant growthpromoting activity of rhizobacteria Pseudomonas sp in Oryza sativa. J. Nat. Prod. Plant Resour. 3:38-50.

Siddiqui, I. A., Shaukat, S. S., Sheikh, I. H. and Khan, A. 2006. Role of cyanide production by Pseudomonas fluorescens
CHA0 in the suppression of root-knot nematode, Meloidogyne javanica in tomato. World J. Microbiol. Biotechnol. 22:641-650.

Silva, H. S. A., Romeiro, R. S. and Mounteer, A. 2003. Development of a root colonization bioassay for rapid screening of rhizobacteria for potential biocontrol agents. J. Phytopathol. 151:42-46.

Singh, A. K. and Kamal, S. 2012. Chemical control of wilt in tomato (Lycopersicon esculentum L.). Int. J. Hortic. 2:5-6.

Sivamani, E. and Gnanamanickam, S. S. 1988. Biological counts of $F$. oxysporum f.sp. cubense in banana by inoculation with Pseudomonas fluorescens. Plant Soil 107:3-9.

Song, W., Zhou, L., Yang, C., Cao, X., Zhang, L. and Liu, X. 2004. Tomato Fusarium wilt and its chemical control strategies in a hydroponic system. Crop Prot. 23:120-123.

Sudini, H., Liles, M. R., Arias, C. R., Bowen, K. L. and Huettel, R. N. 2011. Exploring soil bacterial communities in different peanut-cropping sequences using multiple molecular approaches. Phytopathology 101:819-827.

Suryakala, D., Maheswaridevi, P. U. and Lakshmi, K. V. 2004. Chemical characterization and in vitro antibiosis of siderophores of rhizosphere fluorescent pseudomonads. Indian J. Microbiol. 44:105-108.

Tamura, K. and Nei, M. 1993. Estimation of the number of nucleotide substitutions in the control region of mitochondrial DNA in humans and chimpanzees. Mol. Biol. Evol. 10:512526.

Tans-Kersten, J., Huang, H. and Allen, C. 2001. Ralstonia solanacearum needs motility for invasive virulence on tomato. $J$. Bacteriol. 183:3597-3605.

Van Overbeek, L., Van Veen, J. A. and Van Elsas, J. D. 1997. Induced reporter gene activity, enhanced stress resistance, and competitive ability of a genetically modified Pseudomonas fluorescens strain released into a field plot planted with wheat. Appl. Environ. Microbiol. 63:1965-1973.

Wei, Z., Huang, J., Yang, T., Jousset, A., Xu, Y., Shen, Q. and Friman, V. 2017. Seasonal variation in the biocontrol efficiency of bacterial wilt is driven by temperature-mediated changes in bacterial competitive interactions. J. Appl. Ecol. 54:14401448.

Weller, D. M. and Cook, R. J. 1983. Suppression of take-all of wheat by seed treatments with fluorescent Pseudomonads. Phytopathology 73:463-469.

Whipps, J. M. 1997. Ecological considerations involved in commercial development of biological control agents for soilborne diseases. In: Modern soil microbiology, eds. by J. D. van Elsas, J. T. Trevors and E. M. H. Wellington, pp. 525545. Elsevier, The Netherlands. 